\title{
POT-HOLES AND GLACIER MILLS
}

\author{
$B y$ R. STREIFF-BeCKER (Zürich)
}

\begin{abstract}
Such pot-holes as are caused by glacial action are in the main not due to cascades of melt water falling direct to the glacier bed, but are formed by the subglacial stream when conditions are favourable.

ZUSAMmenfassung. Gletschertöpfe (Strudellöcher) unter einem Gletscher entstehen wohl selten durch direkten Sturz des Schmelzwassers von der Gletscheroberfläche zum Felsuntergrund, sondern in den meisten Fällen durch die wirbelnde Aktion des subglazialen Baches beim Zusammentreffen günstiger Umstände.
\end{abstract}

THE round holes on the rocky banks of torrents with a spherical stone at the bottom are well known. These "pot-holes" are sometimes associated with glacial action and are then often referred to loosely as "glacier mills," or more properly "glacier mill cavities." * The generally accepted explanation of such of these holes as are due to glacial action is that a melt water stream on the glacier surface plunges down through the glacier (as will presently be discussed), hits a large stone on the glacier bed and sets it in rotation, thus excavating a hollow in the rock. This explanation sounds obvious, but the writer cannot fully agree with it.

Not all holes of this nature have any connection with glacial action, as was pointed out by Albert 'Jeim. $\uparrow$ But even those which were formed beneath glaciers cannot, in the author's opinion, have come about in this way, except perhaps very exceptionally.

Few if any observers can have seen the whole process in operation from the time the melt water stream disappeared from the glacier surface, cascaded to the rock bed below and was there scouring out a hollow. As a rule only one or other of these operations can be witnessed.

As we descend a glacier and reach the firn line we find, if the day is hot, that the melted snow and ice gathers into small streams which unite to form larger ones. The water, heated by insolation, meits deep channels in the ice. If the stream reaches a steeper slope where crevasses appear it will naturally flow into one of these (see Fig. I, p. 489) and by devious paths, or under favourable conditions in one leap, reach the glacier bed.

It is well known that crevasses always open at approximately the same place in a glacier when it flows over a convex step in its bed. They gape wide open, and close up again as the slope flattens out (see Fig. 2, p. 489). When a melt water stream (W, Fig. 2) enters a crevasse it melts a more or less cylindrical shaft on the up-hill side of the crevasse wall (II, Fig. 2). This maintains its shape even after the crevasse has ciosed up in its course from II to V. At VI the crevasse has become a barely visible scar but the shaft still remains. These shafts are generally known as moulins or "glacier mills." In German the more appropriate term of "shaft" (Schacht) is often used.

The shaft, now dry since the water has been trapped by a new crevasse, moves on with the ice. Incidentally, these holes with their blue-green irridescent ice walls, following one another at regular intervals, form a striking feature of the glacier scene.

In rare cases these shafts may descend in one leap to the glacier bed, there excavating a true pot-hole in the ordinarily accepted meaning of the term. This is shown diagrammatically in Fig. 3 (p. 489) in which the glacier depth has been very considerably reduced. It must be remembered that the ice is probably several hundred feet deep and that crevasses never reach the glacier bed except sometimes at the snout. It is therefore unlikely that the stream could strike a stone tangentially in an unbroken fall from top to bottom causing it to revolve. But even if it did its changing position would not permit it to play long enough on a given stone to make an appreciable hollow.

- See for instance Tutton. The High Alps. London, 1931, p. 125.

+ Gletscherkunde. Stuttgart, 1885 , p. 544 . 


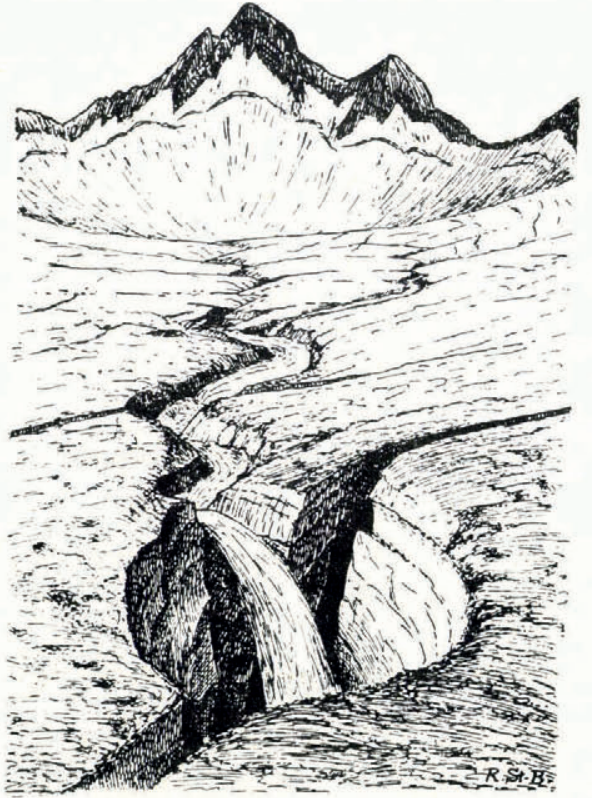

Fig. $\boldsymbol{I}$

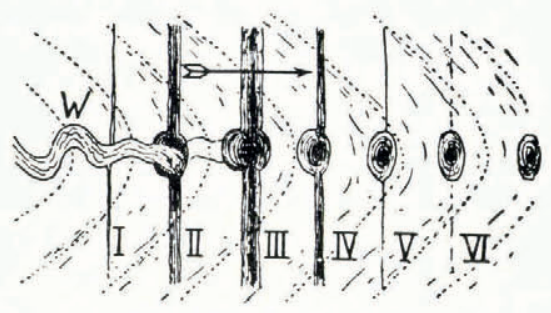

Fig. 2

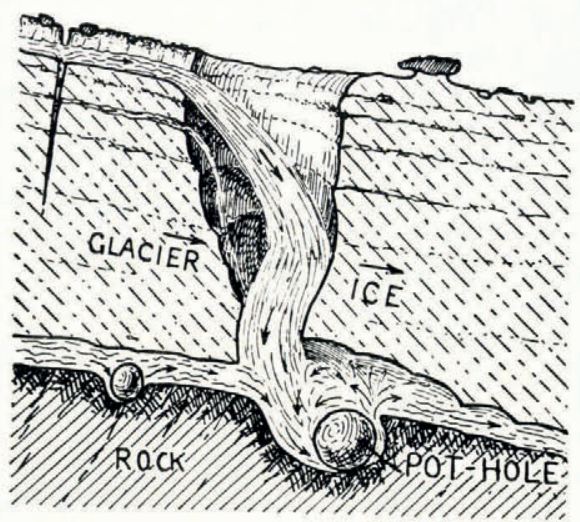

Fig. 3

To the author, then, it seems much more likely that those pot-holes which are due to glacial action were formed by the subglacial stream itself. This runs at high velocity in its confined channel, strikes against a hard bottom moraine in a hollow and sets units of this in rotation. This process is exemplified by the smaller stone in Fig. 3 .

In the famous Gletschergarten of Lucerne, now open to all through the generosity of the Amrein family, one can see a pot-hole on the summit of a roche moutonnée. This has been taken as proof that the hole originated, not in the subglacial stream, but by cascade action through a shaft. In the author's opinion it merely shows that it is older than the roche moutonnée and was formed while the subglacial stream was still running at the level of the summit of the roche moutonne. The excavation of the latter at a later date can be conceived as having taken place by the mechanism suggested by the author * and by Carol. $\dagger$

It is striking that glacier mills, as do roches moutonnées and drumlins, appear in numbers preponderantly behind, and on, steps and buttresses where the glacier once spread out over more level ground. Pot-holes due to glacial action are to be found at various places all over the Alps. Recently particularly beautiful ones in crystalline rocks have been unearthed in the Maloja Pass in the Upper Engadin. Very likely they are distributed all over the world, not only in mountainous

- Vierteljschr. Natf. Ges. in Zürich, Bd. 86, 1941, p. 125.

$\dagger$ Fournal of Glaciology, Vol. 1, No. 2, 1947, p. 57. 
districts but also on more level ground which was covered by glaciers in the glacial period. At the decline of the glaciers they became covered by morainic material and lost to sight. It remains to be seen whether they will stay hidden or whether they will come to light and then be recognised as glacial formations.

MS. received 24 Fune $195^{\circ}$

\title{
POT-HOLES AND GLACIER MILLS \\ SOME COMMENTS ON DR. R. STREIFF-BECKER'S ARTICLE
}

\author{
By S. E. HOLlingworth \\ (University College, London)
}

THE chief obstacle to the solution of this problem is, as Dr. Streiff-Becker indicates, our inability to see the whole process operating at any one place. We must therefore beware of introducing limiting factors of doubtful validity. For instance, would one not be as justified in assuming that a deep pot-hole demands plunge-pool action as in assuming the elimination of the crevasse-toplunge-pool idea by postulation of a thickness of several hundred feet of ice? The elimination of the plunge-pool hypothesis seems to leave us with no adequate agency.

A former glacier bed pot-hole seen in Norway recently was of the order of $20 \mathrm{ft}$. deep plus an unknown thickness of bottom debris. The pot-holes on the Maloja Pass to which Dr. StreiffBecker refers are fine examples of deep cylindrically drilled holes. They are situated on the rocky crest of the pass just where crevassing might be intense.

It is difficult to envisage how sufficient of the essential swirling action could be maintained in a fast flowing subglacial stream to give this type of deep hole if the stream were under a strong hydrostatic head due to high water level in the glacier. Indeed a subglacial stream with a high gradient but in contact with free air and so under no hydrostatic head would provide a better setting.

It is not evident that the subglacial stream hypothesis would account for that apparently accepted concentration of pot-holes at points where crevassing is to be expected. Unfortunately the possible more widespread occurrence of pot-holes beneath drift deposits along valley floors referred to by Dr. Streiff-Becker cannot be readily checked.

A detailed study of the precise location of each deep pot-hole in a glaciated area might reveal an intimate relation to the topography of the rock surface. This might well suggest the possibility of repeated formation of crevasses at favourably located places. Such repitition could give at any such place a surface-water-to-rock-plunge-pool process adequate, in the aggregate, to produce the observed results.

My impression of stream-bed pot-holes in general is that the deep ones are associated with plunge-pool effects in which a free upper water surface is present. Could a similar effect be produced by fast flowing water at the base of waterlogged ice?

We may welcome attention being drawn to this problem, for the whole subject of glacier bed pot-holes and subglacial stream erosion in general merits further study. 